\title{
Changes of physicochemical and microbiological parameters of infiltration water at Debina intake in Poznan, unique conditions - a flood
}

\author{
Sylwia Kołaska ${ }^{1, *}$, Joanna Jeż - Walkowiak ${ }^{1}$, and Zbysław Dymaczewski ${ }^{1}$ \\ ${ }^{1}$ Poznan University of Technology, Faculty of Civil and Environmental Engineering, Berdychowo 4, \\ 60 - 965 Poznan, Poland
}

\begin{abstract}
The paper presents characteristics of Debina infiltration intake which provides water for Poznan and neighbouring communes. The evaluation of effectiveness of infiltration process has been done based on the quality parameters of river water and infiltration water. The analysed water quality parameters are as follows: temperature, iron, manganese, $\mathrm{DOC}_{\mathrm{KMnO}}$, TOC, turbidity, colour, dissolved oxygen, free carbon dioxide, conductivity, total hardness, carbonate hardness, $\mathrm{pH}$, heavy metals, detergents and microorganisms. The paper also includes an assessment of the impact of flood conditions on the quality of infiltration water and operation of infiltration intake. In this part of the paper the following parameters were taken into account: iron, manganese, $\mathrm{DOC}_{\mathrm{KMnO}}, \mathrm{TOC}$, turbidity, colour, dissolved oxygen, free carbon dioxide, conductivity, total hardness, the total number of microorganisms in $36^{\circ} \mathrm{C}$ (mesophilic), the total number of microorganisms in $22^{\circ} \mathrm{C}$ (psychrophilic), coli bacteria, Clostridium perfringens, Escherichia coli, Enterococci. Analysis of the effects of flood on infiltration process leads to the following conclusions: the deterioration of infiltration water quality was due to the deterioration of river water quality, substantial shortening of groundwater passage and partial disappearance of the aeration zone. The observed deterioration of infiltration water quality did not affect the treated water quality, produced at water treatment plant.
\end{abstract}

\section{Introduction}

Infiltration intakes have more than hundred years of tradition [1]. Their implementation were strictly related to decrease of groundwater resources [2]. Among Polish cities which draw water from infiltration intake are Poznan, Warsaw, Cracow, Wroclaw and Legnica fed directly from river bed (riverbank infiltration) and infiltration ponds (artificial infiltration) [3].

Water, after the infiltration process, is transformed into water with the parameters characteristic for groundwater. Its temperature is stable throughout the year, quality

* Corresponding author: sylwia.kolaska@put.poznan.pl 
parameters are improved and their fluctuations which cause difficulties in operating of water treatment plants are smaller (buffering properties of the soil). Technology of a treatment plant employed for the infiltration water is usually the same as for groundwater. In most cases technology is focused on the removal of excessive amounts of iron and manganese from the water and preventive disinfection, however the infiltration process can be less effective and there are also water treatment plants which use technology typical for surface water treatment, for example coagulation [2]. Considering that most of infiltration intakes were created as a result of the development of groundwater intakes, these adjustments in the treatment technology has eliminated a need to build the new water treatment plants, technologically adapted for surface water treatment.

The research presented in this paper is focused on artificial infiltration. In this process water from infiltration ponds goes through a four stage purification process. The first stage occurs in the infiltration pond, where the water quality indicators are averaged. Partial oxidation of ammonia and some organic substances extends in the infiltration pond. Phosphates and nitrates are eliminated at a certain range. Developing algae partly promote decarbonisation of water. In the second stage of water purification, water filters through the natural mineral - biological membrane formed at the base of the pond. Flowing through the membrane and ground layer at the bottom of the pond, water is purified by mechanical filtration, ion exchange, adsorption and biological processes. In this phase the most of heterogeneous impurities are stopped. The next two steps of purification take place in aeration and saturation zones. In the aeration zone as a result of biochemical process, ion exchange or adsorption, contaminants and micro - contaminants are retained. Bacteria and soil fungi, using the oxygen contained in the water, mineralize adsorbed organic pollutants. As water flows to the deeper layers, it is in contact with the increasingly impoverished bacterial environment - the organic substrate is used and the oxygen concentration drops. Products of organic compounds are oxidized by autotrophic bacteria. Carbon dioxide, which is one of the mineralization products, reacts with carbonates in the ground or remains in the water as free/aggressive carbon dioxide. [4]

Presented analyses refer to changes in water quality occurring in Debina intake in Poznan.

\section{The brief description of Debina intake}

Debina infiltration intake covers 247 - $251 \mathrm{~km}$ of the Warta River. Originally formed in 1902, initially it was only groundwater intake. In 1911 a series of 50 wells located along the Warta River were initiated, what started the process of drawing water from riverbank. Due to the increasing demand of water the infiltration ponds were started to be built in 1924. The construction of the ponds were completed in 1964. At that time the capacity in wet years was over $100000 \mathrm{~m}^{3} / \mathrm{d}$ and in dry years was about $80000 \mathrm{~m}^{3} / \mathrm{d}$. Due to the construction of A2 motorway passing through the infiltration intake its capacity has decreased by approximately $20 \%$. The balance of water extraction is: about $70 \%$ - water from infiltration ponds, about $20 \%$ - water from riverbank, about $10 \%$ - groundwater. [4]

\section{Materials and methods}

The paper presents data from 5.5 years of infiltration intake operation. During the period of investigation two floods occurred. To characterise the impact of floods on infiltration water quality the analysis include two years before and two years after the high river level. 
Samples of the Warta River water were taken once a month. As a routine every value of each water quality parameter was determined twice.

Infiltration water was analysed once a week in the period of 5.5 years. Each parameter was analysed two times. Average values of two results were taken into account for the purpose of the further calculation, fatal errors were rejected. Maximum, average and minimum values of water quality parameters were determined.

The values of water quality parameters, physical, chemical and microbiological, were determined according to standard methods. The analyses were performed by certificated laboratory of waterworks.

\section{The quality of river and infiltration water}

To determine the changes occurring in water quality during the infiltration process, a comparative analysis of river water quality and infiltration water has been done. There are selected parameters analysed.

\subsection{Temperature}

As a result of the analysis of temperature data, some characteristic properties of the infiltration process have been observed. This is a reduced amplitude of the infiltration water temperature relative to the amplitude of the water in the Warta River. In the analysed data from 2008 to 2013 the maximum amplitude (measured as the difference of the highest and the lowest temperature) of the Warta River water is $23.5 \mathrm{~K}$, while the amplitude of infiltration water is only $13.5 \mathrm{~K}$ [5]. As was expected the temperature value of infiltration water is stabilised in comparison with the river water. A study done at other infiltration intakes proved the similar trend. Kennewick by the Columbia River has similar trend of change. The maximum amplitude of the Columbia River is $17.8 \mathrm{~K}$, the amplitude of infiltration water is $3.0 \mathrm{~K}$ [6]. Stabilization of water temperature is a beneficial modification that makes process of water treatment easier to lead. Both too high and too low temperature are not good for efficiency of water treatment and cause operational difficulties.

\subsection{Physicochemical parameters}

The following were taken into account: iron and manganese concentration, $\mathrm{DOC}_{\mathrm{KMnO} 4}$, TOC, turbidity, colour, dissolved oxygen, free $\mathrm{CO}_{2}$, conductivity and total hardness collected in the table 1 . 
Table 1. Quality parameters of the Warta River and infiltration water

\begin{tabular}{rrccc|ccc}
\hline parameter & \multicolumn{1}{c}{ unit } & \multicolumn{3}{c}{ Warta River water } & \multicolumn{3}{c}{ infiltration water } \\
\cline { 3 - 8 } iron & $\mathrm{mg} / \mathrm{dm}^{3}$ & 0.896 & 0.206 & 0.508 & 2.100 & 0.032 & 0.434 \\
manganese & $\mathrm{mg} / \mathrm{dm}^{3}$ & 0.420 & 0.001 & 0.110 & 0.429 & 0.015 & 0.298 \\
DOC $_{\mathbf{K M n O 4}}$ & $\mathrm{mgO}_{2} / \mathrm{dm}^{3}$ & 15.10 & 3.70 & 6.79 & 5.50 & 1.10 & 3.05 \\
$\mathbf{T O C}$ & $\mathrm{mg} / \mathrm{dm}^{3}$ & 36.90 & 4.80 & 8.71 & 7.11 & 2.30 & 4.81 \\
turbidity & $\mathrm{NTU}$ & 21.0 & 2.6 & 6.8 & 10.8 & 0.5 & 1.9 \\
colour & $\mathrm{mgPt} / \mathrm{dm}^{3}$ & 70.0 & 10.0 & 23.1 & 65.0 & 7.5 & 11.7 \\
DO & $\mathrm{mg} / \mathrm{dm}^{3}$ & 14.7 & 3.4 & 8.0 & 11.0 & 0.9 & 3.6 \\
free CO & $\mathrm{mg} / \mathrm{dm}^{3}$ & 17.6 & 0.0 & 4.6 & 53.5 & 3.0 & 21.3 \\
conductivity & $\mu \mathrm{S} / \mathrm{cm}^{2}$ & 742.0 & 506.0 & 604.7 & 713.0 & 578.0 & 644.5 \\
total & $\mathrm{mgCaCO} /$ & 322.0 & 180.0 & 245.0 & 311.0 & 226.0 & 265.0 \\
hardness & $\mathrm{dm}^{3}$ & & & & & & \\
\hline
\end{tabular}

Analysing the data summarised in the table 1 it is surprising that the average concentration of iron in infiltration water is less than in the Warta River water. Despite the fact that maximum concentration of iron in infiltration water exceeds more than two times the maximum concentration of iron in the Warta River water, the average result indicates the decreasing tendency in the iron concentration after the infiltration process. This may occur due to quality of underground water mixed with infiltration water and the geological conditions in Debina intake. As was expected - the average concentration of manganese increases 2.7 times after the infiltration process. This indicates a supply of groundwater reach in manganese and the location of infiltration intake on the soil which is reach in that compound [7]. The $\mathrm{DOC}_{\mathrm{KMnO} 4}$ of infiltration water decreases more than twice comparing to the $\mathrm{DOC}_{\mathrm{KMnO} 4}$ of the Warta River water and finally achieves quality requirements regarding the water intended for consumption, defined at $5 \mathrm{mgO}_{2} / \mathrm{dm}^{3}$ (except the time when it reaches maximum values). The TOC value drops almost twice after the infiltration process and also achieves requirements for water intended for human consumption $\left(5 \mathrm{mg} / \mathrm{dm}^{3}\right)$ for the average value. The turbidity of the water after the infiltration process drops more than 3.5 times. Finally, the average value exceeds the permissible turbidity of drinking water almost twice ( $\max 1 \mathrm{NTU}$ ). The colour is reduced twice after the infiltration process. Finally the colour in its average value falls within the standards, but its maximum value exceeds the level of $15 \mathrm{mgPt} / \mathrm{dm}^{3}$ (currently the acceptable colour value is defined as acceptable for a consumer). Infiltration water, through the flow in the reducing ground environment, is deoxidized and enriched by free $\mathrm{CO}_{2}$. Significant increase in carbon dioxide in infiltration water is a sign of the intensity of chemical and biological processes in infiltration water. The Warta River water is characterized by a greater amplitude of conductivity variations, but average conductivity value is higher in infiltration water. Water conductivity about $600 \mu \mathrm{S} / \mathrm{cm}$ is appropriate for drinking water which should range from 300 to $1200 \mu \mathrm{S} / \mathrm{cm}$. The average value of total hardness increases by $20 \mathrm{mgCaCO} / \mathrm{dm}^{3}$ after the infiltration process. The appropriate level of total hardness for drinking water is between $60-500 \mathrm{mgCaCO} / \mathrm{dm}^{3}$, infiltration water is in this range. [5]

\subsection{Heavy metals in the Warta River water and infiltration water}

Heavy metals concentration such as lead, copper, chromium and nickel were analysed. The data are presented in fig. 1. 

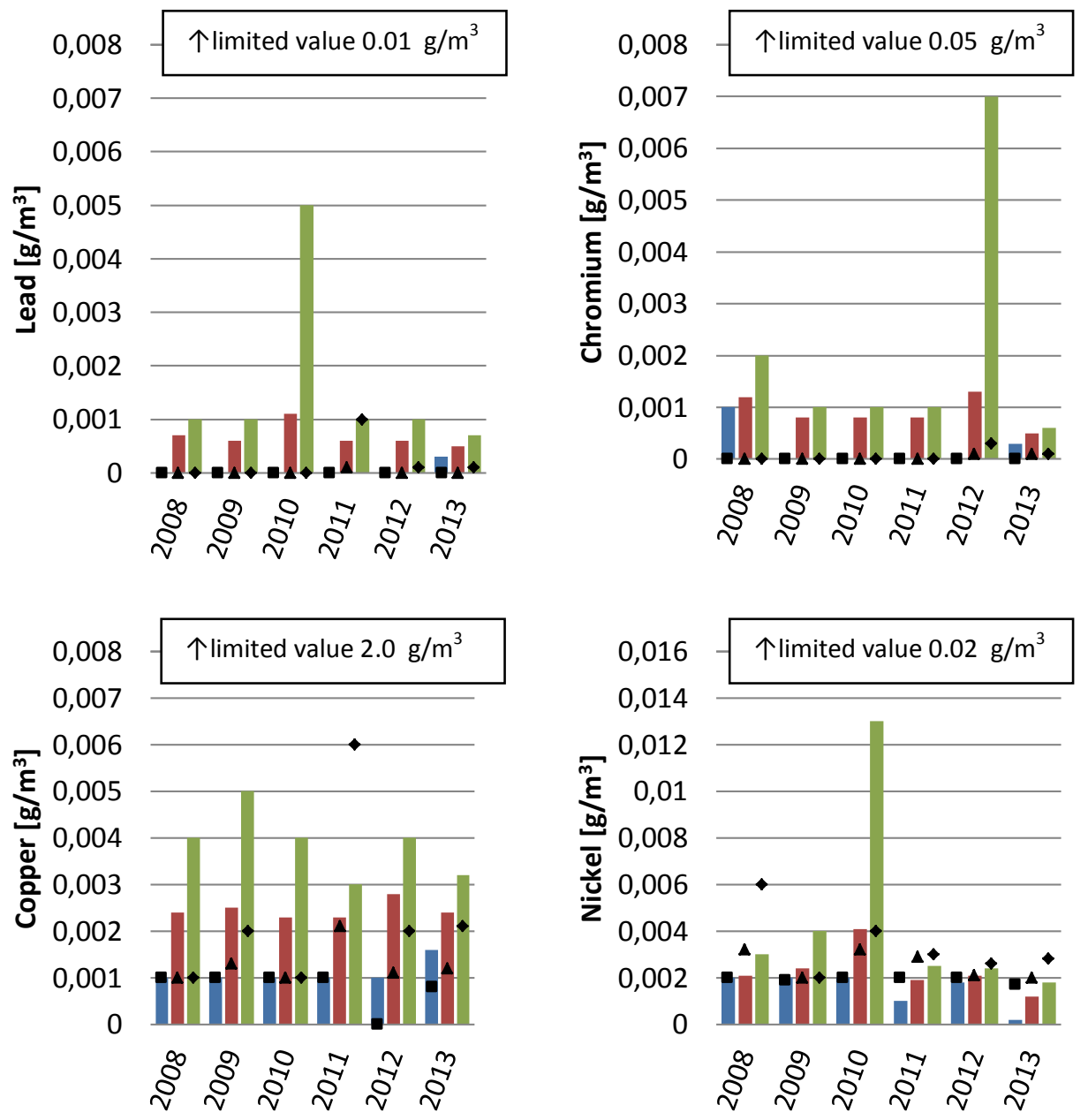

- $\mathrm{m}$ in Warta River avg Warta River - max Warta River
- $\mathrm{m}$ in infiltration water $\Delta$ avg infiltration water • max infiltration water

Figure 1. Heavy metals concentration parameters in the Warta River water and infiltration water

The samples were taken usually once a month. In addition to the average value, the minimum and maximum values were also determined. The limited values for drinking water are also presented on the graphs for selected heavy metals. The efficiency of infiltration process was calculated based on the average values, according to the formula 1 :

$$
E_{i}=\frac{\left(c_{\text {in }}\right)_{i}-\left(c_{\text {out }}\right)_{i}}{\left(c_{\text {in }}\right)_{i}} \cdot 100
$$

$c_{i n}, c_{\text {out }}-$ concentrations of $\mathrm{i}$ - heavy metal in the river and after infiltration process, $\mathrm{g} / \mathrm{m}^{3}$.

In the period of research the concentration of heavy metals were low in river and infiltration water, below the limited values. In 2008 - 2013 the lead average concentration 
in the Warta River had been consistently low at around $0.0006 \mathrm{~g} / \mathrm{m}^{3}$. Only in 2010 that concentration had exceeded the average value of $0.001 \mathrm{~g} / \mathrm{m}^{3}$, what is still almost ten times lower than allowed by the standards regarding drinking water. The efficiency of the infiltration process ranged from $82-100 \%$, thus giving a satisfying result showing the ability of infiltration process to reduce the lead concentration.

In 2008 chromium average concentration in the Warta River was $0.0012 \mathrm{~g} / \mathrm{m}^{3}$. In 2009 2011 the chromium concentration did not exceed $0.0008 \mathrm{~g} / \mathrm{m}^{3}$. In 2012 it had temporarily increased to $0.0013 \mathrm{~g} / \mathrm{m}^{3}$ and a year later dropped to $0.0005 \mathrm{~g} / \mathrm{m}^{3}$. The effectiveness of the process during the first four years was $100 \%$. In the next two years, it slightly decreased to $91 \%$ and $83 \%$, but did not exceed the limit value for drinking water which is $0.05 \mathrm{~g} / \mathrm{m}^{3}$.

In 2008 - 2013 the average concentration of copper in the Warta River water fluctuated around $0.0025 \mathrm{~g} / \mathrm{m}^{3}$, whereas in infiltration water about $0.001 \mathrm{~g} / \mathrm{m}^{3}$, resulting in the efficiency of the process from $42 \%$ to $60 \%$ excluding 2011 year, where the efficiency value was only $6.2 \%$. The permissible concentration of copper in drinking water is $2 \mathrm{~g} / \mathrm{m}^{3}$.

The average concentration of nickel in the Warta River water in $2008-2013$ was in the range of $0.0012 \mathrm{~g} / \mathrm{m}^{3}$ to $0.0041 \mathrm{~g} / \mathrm{m}^{3}$. In 2009 and 2010 years there had been the elimination of the metal at about $20 \%$, while in 2008 and 2011 - 2013 an increase in the concentration of nickel in infiltration water occurred. The permissible concentration of nickel in drinking water is $0.02 \mathrm{~g} / \mathrm{m}^{3}$ and even under the influence of the increase in nickel concentration after infiltration process, the values are still ten times less than permissible.

The highest concentration of lead, chromium and nickel occur in individual cases and slightly increase the average value for the year.

During analysis of metal concentration in infiltration water both tendencies - for decrease and increase of metal concentrations in infiltration water - can be noticed. The increase in metal concentration is probably caused by the change of steady water parameters, such as $\mathrm{pH}$, which releases prematurely adsorbed particles from the ground or to exceptional conditions in the Warta River [8]. Despite the occasional increase in concentration of some heavy metals, in any of the analysed cases the concentration of metals in infiltration water did not exceed the limit value specified in the Regulation of the Minister of Health in Poland.

\subsection{Detergents in the Warta River water and infiltration water}

In table 2 the concentration of detergents is presented.

Table 2. The detergents concentration parameters in Warta River and infiltration water

\begin{tabular}{|c|c|c|c|c|c|c|c|}
\hline \multirow[t]{2}{*}{ year } & \multicolumn{3}{|c|}{$\begin{array}{c}\text { detergents in Warta River } \\
\text { water } \\
{\left[\mathrm{g} / \mathrm{m}^{3}\right]}\end{array}$} & \multicolumn{3}{|c|}{$\begin{array}{c}\text { detergents in infiltration } \\
\text { water } \\
{\left[\mathrm{g} / \mathrm{m}^{3}\right]}\end{array}$} & \multirow[t]{2}{*}{$\begin{array}{c}\text { infiltration } \\
\text { efficiency } \\
{[\%]}\end{array}$} \\
\hline & $\max$ & $\min$ & average & $\max$ & $\min$ & average & \\
\hline 2008 & 0.280 & 0.140 & 0.197 & 0.100 & 0.060 & $0.077^{\circ}$ & 61.1 \\
\hline 2009 & 0.350 & 0.110 & 0.195 & 0.100 & 0.070 & 0.080 & 59.0 \\
\hline 2010 & 0.360 & 0.070 & 0.204 & 0.160 & 0.070 & 0.123 & 40.1 \\
\hline 2011 & 0.460 & 0.140 & 0.360 & 0.400 & 0.050 & 0.313 & 13.2 \\
\hline 2012 & 0.650 & 0.210 & 0.436 & 0.420 & 0.420 & 0.420 & 3.7 \\
\hline 2013 & 0.420 & 0.160 & 0.320 & 0.230 & 0.050 & 0.140 & 56.3 \\
\hline
\end{tabular}

Since 2011 there had been a noticeable increase in the concentration of detergents in the Warta River water. Concentration had increased about twice in comparison to the three previous years $(2008-2010)$. Starting with average value of about $0.2 \mathrm{~g} / \mathrm{m}^{3}$ it finally oscillated around $0.4 \mathrm{~g} / \mathrm{m}^{3}$ and more. This is probably due to the fact that population is 
using more and more surfactants, which are contaminating ground water. The effectiveness of the process in the first two years after the increase in concentration of detergents in the Warta River significantly decreased - from values close to $60 \%$ in 2008 and 2009 to $3.7 \%$ in 2012. However, a year later the efficiency again increased to $56.3 \%$, as well as surfactants concentration in the Warta River water slightly decreased.

\subsection{Chemical stability of the Warta River water and infiltration water}

Parameters related to chemical stability of water are presented in table 3 . The infiltration water is characterised by higher value of carbonate hardness (alkalinity) than the Warta River water. The $\mathrm{pH}$ value of infiltration water is lower than the Warta River water.

To evaluate the chemical stability of the Warta River water and infiltration water the LSI - Langelier Saturation Index was calculated and presented in table 3 as well. The value of LSI was calculated according to the formula 2:

$$
L S I=p H-p H_{\text {stability }}
$$

where:

$\mathrm{pH}_{\text {stability }}$ is a saturation $\mathrm{pH}$.

According to presented data the river water is supersaturated with respect to calcium carbonate $\left(\mathrm{CaCO}_{3}\right)$ and scale forming may occur $(\mathrm{LSI}>0)$. After the infiltration the water reaches the calcium-carbonate equilibrium $(\mathrm{LSI}=0)$. [9]

Table 3. Chemical stability parameters of the Warta River and infiltration water

\begin{tabular}{|c|c|c|c|c|c|c|c|c|c|c|c|}
\hline \multirow[t]{2}{*}{ parameter } & \multirow[t]{2}{*}{ unit } & \multicolumn{5}{|c|}{ Warta River water } & \multicolumn{5}{|c|}{ infiltration water } \\
\hline & & $\begin{array}{l}\text { avg. } \\
\text { spr. }\end{array}$ & $\begin{array}{l}\text { avg. } \\
\text { sum. }\end{array}$ & $\begin{array}{l}\text { avg. } \\
\text { aut. }\end{array}$ & $\begin{array}{l}\text { avg. } \\
\text { win. }\end{array}$ & $\begin{array}{l}\text { avg. } \\
\text { wh. } \\
\text { per. }\end{array}$ & $\begin{array}{l}\text { avg. } \\
\text { spr. }\end{array}$ & $\begin{array}{l}\text { avg. } \\
\text { sum. }\end{array}$ & $\begin{array}{l}\text { avg. } \\
\text { aut. }\end{array}$ & $\begin{array}{l}\text { avg. } \\
\text { win. }\end{array}$ & $\begin{array}{l}\text { avg. } \\
\text { wh. } \\
\text { per. }\end{array}$ \\
\hline $\begin{array}{r}\text { carbonate } \\
\text { hardness }\end{array}$ & $\begin{array}{r}\mathrm{mgCaCO}_{3} / \\
\mathrm{dm}^{3}\end{array}$ & 171 & 163 & 175 & 178 & 171 & 191 & 191 & 187 & 187 & 189 \\
\hline $\mathbf{p H}$ & - & 8.1 & 8.1 & 8.0 & 7.9 & 8.0 & 7.4 & 7.4 & 7.4 & 7.4 & 7.4 \\
\hline $\mathbf{p H}_{\text {stability }}$ & - & 7.5 & 7.5 & 7.5 & 7.4 & 7.5 & 7.4 & 7.4 & 7.4 & 7.4 & 7.4 \\
\hline LSI & - & 0.6 & 0.6 & 0.5 & 0.5 & 0.5 & 0 & 0 & 0 & 0 & 0 \\
\hline
\end{tabular}

spr. - spring; sum. - summer; aut. - autumn; win. - winter; wh. per. - whole period

\subsection{Microbiological parameters}

The following groups of bacteria were taken into account: coli bacteria, Escherichia coli, Clostridium perfringens and Enterococci. The article presents results of the removal of Escherichia coli (table 4), but when it comes to the other kinds of bacteria the efficiency of the process is comparable, always almost $100 \%$. 
Table 4. The Escherichia coli concentration parameters in the Warta River and infiltration water

\begin{tabular}{|c|c|c|c|c|c|c|c|}
\hline \multirow[t]{2}{*}{ year } & \multicolumn{3}{|c|}{$\begin{array}{c}\text { Escherichia coli } \\
\text { in Warta River water } \\
\text { [MPN in } 100 \mathrm{ml}]\end{array}$} & \multicolumn{3}{|c|}{$\begin{array}{c}\text { Escherichia coli } \\
\text { in infiltration water } \\
\text { [MPN in } 100 \mathrm{ml}]\end{array}$} & \multirow[t]{2}{*}{$\begin{array}{c}\text { infiltration } \\
\text { efficiency } \\
{[\%]}\end{array}$} \\
\hline & $\max$ & $\min$ & average & $\max$ & $\min$ & average & \\
\hline 2008 & 5000 & 140 & 1431 & 0 & 0 & 0 & 100 \\
\hline 2009 & 5172 & 270 & 1402 & 0 & 0 & 0 & 100 \\
\hline 2010 & 1401 & 100 & 598 & 9 & 0 & 0 & 99.960 \\
\hline 2011 & 2600 & 110 & 663 & 3 & 0 & 0 & 99.978 \\
\hline 2012 & 2610 & 55 & 642 & 0 & 0 & 0 & 100 \\
\hline 2013 & 4500 & 246 & 1516 & 1 & 0 & 0 & 99.997 \\
\hline
\end{tabular}

Between 2010 and 2012 there was more than twice decrease in Escherichia coli concentration in the Warta River. Unfortunately, in 2013 the number of Escherichia coli had returned to the level noticed before 2010. Worse parameters of the infiltration water quality in 2010 and 2011 were related to summer flood in 2010 and winter flood in 2010/ 2011. After the infiltration process Escherichia coli is reduced almost in $100 \%$.

\section{River and infiltration water quality during floods}

Two periods of alarm condition in the Warta River were taken into account. The first is the summer flood from May to June 2010 and the second is the winter flood 2010/ 2011. The parameters were the same as in the list of parameters for the river and infiltration water quality (table 5).

Table 5. Quality of the Warta River and infiltration water during flood periods

\begin{tabular}{|c|c|c|c|c|}
\hline \multirow[b]{2}{*}{ parameter } & \multirow[b]{2}{*}{ unit } & \multicolumn{2}{|c|}{$\begin{array}{c}\text { summer flood } \\
\mathbf{2 6 . 0 5}-\mathbf{1 8 . 0 6 . 2 0 1 0}\end{array}$} & $\begin{array}{c}\text { winter flood } \\
24.11 .-24.02 .2011 \\
\end{array}$ \\
\hline & & $\begin{array}{c}\text { Warta River } \\
\text { water }\end{array}$ & $\begin{array}{c}\text { infiltration } \\
\text { water }\end{array}$ & $\begin{array}{c}\text { infiltration } \\
\text { water }\end{array}$ \\
\hline iron & $\mathrm{mg} / \mathrm{dm}^{3}$ & $0.454-0.762$ & $0.338-0.691$ & $0.184-0.604$ \\
\hline manganese & $\mathrm{mg} / \mathrm{dm}^{3}$ & $0.056-0.250$ & $0.300-0.410$ & $0.280-0.370$ \\
\hline DOC $_{\mathrm{KMnO4}}$ & $\mathrm{mgO}_{2} / \mathrm{dm}^{3}$ & $12.20-15.10$ & $3.10-5.50$ & $3.21-4.06$ \\
\hline TOC & $\mathrm{mg} / \mathrm{dm}^{3}$ & $15.76-17.16$ & $5.97-7.11$ & $5.76-6.22$ \\
\hline turbidity & NTU & $2.60-4.91$ & $1.22-1.74$ & $0.95-3.19$ \\
\hline colour & $\mathrm{mgPt} / \mathrm{dm}^{3}$ & $60-70$ & $7.5-25$ & $10-20$ \\
\hline DO & $\mathrm{mg} / \mathrm{dm}^{3}$ & $4.6-5.5$ & $1.9-2.6$ & $3.3-5.7$ \\
\hline free $\mathrm{CO}_{2}$ & $\mathrm{mg} / \mathrm{dm}^{3}$ & $7.48-17.60$ & $23.54-26.18$ & $24.20-53.46$ \\
\hline conductivity & $\mu \mathrm{S} / \mathrm{cm}$ & $532-556$ & $630-678$ & $641-691$ \\
\hline $\begin{array}{r}\text { total } \\
\text { hardness }\end{array}$ & $\begin{array}{r}\mathrm{mgCaCO}_{3} / \\
\mathrm{dm}^{3}\end{array}$ & $248-249$ & $265-277$ & $274-311$ \\
\hline
\end{tabular}

The river water and infiltration water quality during the flood was deteriorated. To describe the intensity of the water quality deterioration the instability coefficient - IC was introduced. The value of IC was calculated according to the formula 3:

$$
I C=\frac{A F}{A V}
$$

where:

$\mathrm{AF}$ is an average value of analysed parameter during the flood time, 
$\mathrm{AV}$ is an average value of analysed parameter during 5.5 years of intake operation without flood period.

\section{IC - summer and winter floods}

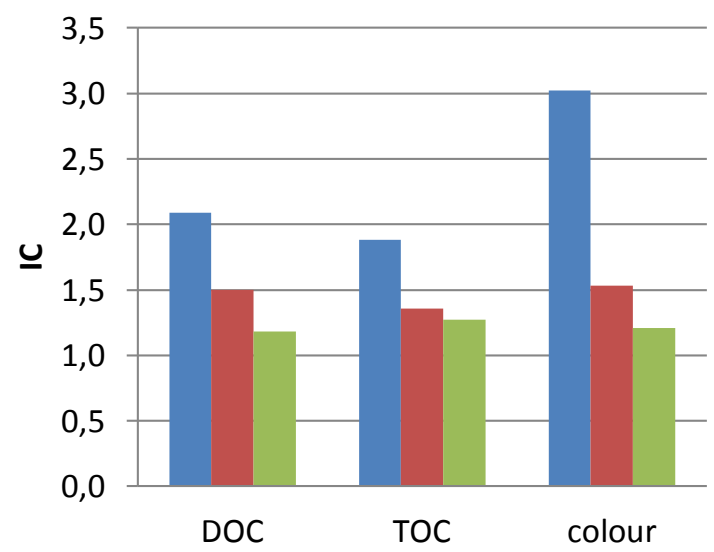

Warta River summer flood

- infiltration water summer flood

infiltration water winter flood

Figure 2. Instability coefficient for $\mathrm{DOC}_{\mathrm{KMnO}}, \mathrm{TOC}$ and colour

The results of IC values for selected important parameters are presented in figure 2. Comparison of IC values in river and infiltration water allowed to evaluate the buffering properties of infiltration ground passage for chosen parameters. During summer flood IC for $\mathrm{DOC}_{\mathrm{KMnO} 4}$ in the river is 2.09 compare to 1.5 in infiltration water. IC for TOC in the river is 1.88 , in infiltration water is 1.36 . For colour IC in the river is 3.02 , in infiltration water 1.53 - almost twice times more. During winter flood only IC for infiltration water were taken into account. In the winter flood instability of water parameters is lower: $I C_{\text {DOCKMnO4 }}$ is $1.18, I C_{\text {TOC }}$ is 1.27 and $I C_{\text {colour }}$ is 1.21 .

$I C_{\text {DOCKMnO4 }}, I C_{\text {TOC }}$ and $I C_{\text {colour }}$ accurately reflect changes during the floods. In the summer flood water's pollution is higher than during the winter flood. More variation in stability parameters are in the Warta River water than in the infiltration water - the soil has buffering properties.

Referring to the data from 5.5 years of exploitation of the infiltration intake, including flood periods, it can be noticed that during floods:

- in the case of summer flood parameters of the Warta River water quality are usually above average, reaching their maximum levels in the case of $\mathrm{DOC}_{\mathrm{KMnO} 4}$ $\left(15.10 \mathrm{mgO} / 2 \mathrm{dm}^{3}\right)$, colour $\left(70 \mathrm{mgPt} / \mathrm{dm}^{3}\right)$ and free $\mathrm{CO}_{2}\left(17.6 \mathrm{mg} / \mathrm{dm}^{3}\right)$;

- the infiltration water during summer flood also reaches its maximum values for such parameters as: $\mathrm{DOC}_{\mathrm{KMnO} 4}\left(5.5 \mathrm{mgO}_{2} / \mathrm{dm}^{3}\right)$ and TOC $\left(7.11 \mathrm{mg} / \mathrm{dm}^{3}\right)$;

- during winter flood water quality parameters associated with contamination are also above average level;

In addition, the microbiological parameters of the Warta River water and infiltration water were analysed. The noticed regularities were presented in the summary table 6 . 
Table 6. Microbiological parameters during flood periods

\begin{tabular}{|c|c|c|c|}
\hline \multirow[t]{2}{*}{ parameter } & \multirow{2}{*}{$\begin{array}{c}\text { Warta River water } \\
\text { summer flood }\end{array}$} & \multicolumn{2}{|c|}{ infiltration water } \\
\hline & & summer flood & winter flood \\
\hline $\begin{array}{l}\text { Total number of } \\
\text { microorganisms } \\
\text { at } 36^{\circ} \mathrm{C} \\
\text { after } 48 \mathrm{~h}\end{array}$ & no data & $\begin{array}{l}4-263 \\
\text { CFU/1ml }\end{array}$ & $\begin{array}{l}\text { range: } 5-170 \mathrm{CFU} / 1 \mathrm{ml} \\
\text { average: } 76 \mathrm{CFU} / 1 \mathrm{ml}\end{array}$ \\
\hline $\begin{array}{l}\text { Total number of } \\
\text { microorganisms } \\
\text { at } 22^{\circ} \mathrm{C} \\
\text { after } 72 \mathrm{~h}\end{array}$ & no data & $\begin{array}{l}2-1510 \\
\mathrm{CFU} / 1 \mathrm{ml}\end{array}$ & $\begin{array}{l}\text { range: } 6-590 \mathrm{CFU} / 1 \mathrm{ml} \\
\text { average: } 164 \mathrm{CFU} / 1 \mathrm{ml}\end{array}$ \\
\hline $\begin{array}{l}\text { Coli bacteria } \\
\text { colilert method }\end{array}$ & $\begin{array}{l}1600-4350 \\
\text { MPN in } 100 \mathrm{ml}\end{array}$ & $\begin{array}{l}0-613 \\
\text { MPN in } 100 \mathrm{ml}\end{array}$ & $\begin{array}{l}\text { range: } 0-11 \mathrm{MPN} \text { in } 100 \mathrm{ml} \\
\text { average: } 4.4 \mathrm{MPN} \text { in } 100 \mathrm{ml}\end{array}$ \\
\hline $\begin{array}{l}\text { Escherichia coli } \\
\text { colilert method }\end{array}$ & $\begin{array}{l}100-166 \\
\text { MPN in } 100 \mathrm{ml}\end{array}$ & $\begin{array}{l}0-9 \\
\text { MPN in } 100 \mathrm{ml}\end{array}$ & $\begin{array}{l}\text { range: } 0-3 \mathrm{MPN} \text { in } 100 \mathrm{ml} \\
\text { average: } 0.5 \mathrm{MPN} \text { in } 100 \mathrm{ml}\end{array}$ \\
\hline $\begin{array}{l}\text { Clostridium } \\
\text { perfringens }\end{array}$ & $\begin{array}{l}140-200 \\
\mathrm{CFU} / 100 \mathrm{ml}\end{array}$ & $\begin{array}{l}0-1 \\
\mathrm{CFU} / 100 \mathrm{ml}\end{array}$ & $\begin{array}{l}\text { range: } 0-1 \mathrm{CFU} / 100 \mathrm{ml} \\
\text { average: } 0.3 \mathrm{CFU} / 100 \mathrm{ml}\end{array}$ \\
\hline $\begin{array}{l}\text { Enterococci } \\
\text { (Streptococci) } \\
\text { enterolert } \\
\text { method }\end{array}$ & $\begin{array}{l}120-192 \\
\text { MPN in } 100 \mathrm{ml}\end{array}$ & $\begin{array}{l}0-22 \\
\text { MPN in } 100 \mathrm{ml}\end{array}$ & $\begin{array}{l}\text { range: } 0-1 \mathrm{MPN} \text { in } 100 \mathrm{ml} \\
\text { average: } 0.3 \mathrm{MPN} \text { in } 100 \mathrm{ml}\end{array}$ \\
\hline
\end{tabular}

The results from tables 5 and 6 show the potential threat to the stability of the infiltration water parameters during floods. Deterioration of the infiltration water parameters is caused by the flooding of the infiltration area - shortening the infiltration zone. In case of wells leakage, contamination of captured water may occur and in the result the intake may stop to function. However on Debina intake there were no major problems with drinking water production during the flood periods due to the high efficiency of water treatment technology applied for infiltration water treatment.

Current modernization of Debina intake aims to protect infiltration water from flood by elevation of the ground level and hermetic closure of the wells.

\section{Conclusions}

The infiltration process stabilizes temperature of water and simplifies the further processes on infiltration water treatment plant. The parameters of infiltration water are similar to the parameters of groundwater, so treatment technology typical for groundwater treatment can be effective. Colour and turbidity - characteristic water quality parameter of surface water, are significantly reduced after the infiltration. Concentration of manganese increased after infiltration process. [10]

In the analysed period at Debina intake problems with exceeding the concentration of heavy metals in the river and infiltration water were not reported. Periodically there is a tendency to elution of some heavy metals from the ground.

The infiltration process effectively eliminates the microbiological contaminants from water. In the most of analysed samples no bacteria were detected and the reduction of the 
bacteria always was more than $99 \%$. Two floods had occurred in the analysed period. First in May - June 2010 and the second one from November 2010 to February 2011. During floods, the parameters of the river water and infiltration water were worse. Especially during the summer flood unfavourable changes were more intensive. The calculated instability coefficients (IC) for selected parameters: $\mathrm{DOC}_{\mathrm{KMnO}}$, TOC and colour, show the intensity of water quality changes during flood periods. They indicate the buffering properties of the infiltration process, minimizing the effect of river water deterioration on infiltration water quality during the flood. After analysis of the data, it can be clearly stated that infiltration intakes seem to be a perfect system for natural and ecological water treatment, which replaces complex process with the usage of chemicals in surface water treatment plants.

\section{References}

1. W.D. Gollnitz, J.L. Clancy, B.L. Whitteberry, J.A. Vogot, Journal American Water Works Association, 95/12, 56 - 66 (2003)

2. A. L. Kowal, Ochrona środowiska, 2, 5 - 7 (1983)

3. M. Sozański (ed.), Wodociagi i kanalizacja w Polsce, tradycja i wspótczesność (Polska Fundacja Ochrony Zasobów Wodnych, Poznań- Bydgoszcz, 2002)

4. A. Bartosik, I. Chomicki, T. Jankowski, Ochrona środowiska, 3, 51 - 54 (2007)

5. S. Kołaska, I. Chomicki, Instal, 7/8 (364), 66 - 69 (2015)

6. S. Mikels, Journal American Water Works Association, 84/9, 77 - 84 (1992)

7. A. L. Kowal, M. Świderska - Bróż, Ochrona środowiska, 2, 5 - 7 (1983)

8. M. Błażejewski, Ochrona środowiska, 2, 7 - 13 (1983)

9. Falewicz P., Drela I., Kuczkowska S., Ochrona przed korozją, 4/5, 187 - 191 (2008)

10. A. L. Kowal, M. Świderska - Bróż, Oczyszczanie wody (Wydawnictwo Naukowe PWN, Warszawa - Wrocław 2000) 